\title{
Nursing assessment: the elaboration and development of a massive open online course
}

\author{
Avaliação de enfermagem: elaboração e desenvolvimento \\ de um curso massivo, aberto e online
}

Valoración de enfermería: elaboración y desarrollo de un curso massivo, abierto y online

\section{Cibele Duarte Parulla ${ }^{a}$ \\ Daniel Magno Galdino ${ }^{b}$ \\ Daiane Dal Paic \\ Karina de Oliveira Azzolin' \\ Ana Luísa Petersen Cogoc}

\section{How to cite this article:}

Parulla CD, Galdino DM, Dal Pai D, Azzolin

KO, Cogo ALP. Nursing Assessment: the elaboration and development of a massive open online course. Rev Gaúcha Enferm. 2020:41(esp):e20190199. doi: https://doi.org/10.1590/19831447.2020.20190199
"Universidade Federal do Rio Grande do Sul (UFRGS), Escola de Enfermagem, Programa de Pós-Graduaçăo em Enfermagem. Porto Alegre, Rio Grande do Sul, Brasil.

${ }^{\circ}$ Universidade Federal do Rio Grande do Sul (UFRGS), EscoladeEnfermagem, Cursode Graduaçãoem Enfermagem. Porto Alegre, Rio Grande do Sul, Brasil.

' Universidade Federal do Rio Grande do Sul (UFRGS), Escola de Enfermagem, Departamento de Enfermagem Médico-Cirúrgica. Porto Alegre, Rio Grande do Sul, Brasil.

\section{ABSTRACT}

Objective: Describing the stages of elaboration and development of a massive open online course on "Nursing Assessment".

Method: Experience report of the construction of a free course, developed between 2015 and 2016 with the partnership of the School of Nursing and the Nucleus of Support to Distance Learning. The course was hosted on the Lúmina platform.

Results: The construction of the course began in 2015 and the first edition was made available in September 2016, with 693 participants. The aim of the choice and elaboration of the material was to design an attractive and quality course for the community. The stages observed in its elaboration were choice of theme, course production, preliminary assessment and launching the first edition.

Conclusions: The course has been shown to be a support for in-class teaching, as well as for the continuing education of health professionals.

Keywords: Nursing. Education, nursing. Education, distance. Educational technology.

\section{RESUMO}

Objetivo: Descrever as etapas de elaboração e desenvolvimento de um curso massivo, aberto e online sobre "Avaliação de Enfermagem".

Método: Relato de experiência da construção de um curso gratuito, desenvolvido entre os anos de 2015 e 2016 com a parceria da Escola de Enfermagem e do Núcleo de Apoio ao Ensino a Distância. 0 curso está hospedado na plataforma Lúmina.

Resultados: A construção do curso teve início em 2015 e a primeira edição foi disponibilizada em setembro de 2016 com 693 inscritos. During the choice and elaboration of the materials, the aim was conceiving a quality course that was attractive to the community. As etapas observadas na sua elaboração foram escolha do tema, produção do curso, avaliação preliminar e lançamento da primeira edição.

Conclusões: 0 curso demonstrou ser um apoio ao ensino presencial, bem como à educação permanente dos profissionais da saúde. Palavras-chave: Enfermagem. Educação em enfermagem. Educação a distância. Tecnologia educacional.

\section{RESUMEN}

Objetivo: Describir las etapas de elaboración y desarrollo de un curso masivo, abierto y online sobre "Valoración de Enfermería".

Método: Relato de experiencia de la construcción de un curso gratuito, desarrollado entre los años 2015 y 2016 con la asociación de la Escuela de Enfermería y el Núcleo de Apoyo a la Enseñanza a Distancia. El curso fue hospedado en la plataforma Lúmina.

Resultados: La construcción del curso comenzó en 2015 y a la primera edición se puso a disposición en septiembre de 2016 con 693 inscritos. La preocupación en la elección y elaboración del material fue la de concebir un curso atractivo y de calidad para la comunidad. Las etapas observadas en su elaboración fueron la elección del tema, producción del curso, evaluación preliminar y lanzamiento de la primera edición.

Conclusiones: El curso demostró ser un apoyo a la enseñanza presencial, así como a la educación permanente de los profesionales de la salud.

Palabras clave: Enfermería. Educación en enfermería. Educación a distancia. Tecnología educacional. 


\section{INTRODUCTION}

The Massive Open Online Courses (MOOCs) are educational activities in virtual environments developed in academic settings from 2008 on, offering access to many types of knowledge to a wide number of participants ${ }^{(1-2)}$. From this perspective, the MOOCs offer its participants a part on the construction of their own paths towards learning, and may also make it possible for them to share knowledge with one another ${ }^{(2-3)}$

The MOOCs are learning tools that offer schedule flexibility, quality material, and low cost, and are seen as positive mechanisms for continued education ${ }^{(4)}$. These courses make it possible for professionals to acquire new abilities and stay up-to-date in their field of knowledge ${ }^{(5)}$. In addition, MOOCs have the potential to overcome the limits of current learning strategies, making high quality education available for a much larger and diverse group of participants, who can interact even if geographically distant ${ }^{(6-7)}$.

This course modality was not created to substitute in-class learning, but it is a way to allow course participants to access free and open activities, offered by respected institutions. It can even be used as a strategy for hybrid teaching and give support to in-class classes ${ }^{(8)}$. The courses are offered in dedicated platforms and can use social networks as a support ${ }^{(3)}$. In the field of health, $\mathrm{MOOC}$ production is still restricted when compared to other fields of knowledge, such as the exact sciences. A study that surveyed all 4.593 courses available in the MOOC-List.com website found 376 courses in the field "health and society", only $8.19 \%$ of the total ${ }^{(9)}$.

In 2016, the Universidade Federal do Rio Grande do Sul (UFRGS) created the Lúmina platform to host the courses of this type which were offered by the institution itself. Professionals from the Nursing School began producing the MOOC "Nursing Assessment", which was one of the first courses to be made available at Lúmina.

This study aims at describing the stages of elaboration and development of a massive online open course about "Nursing Assessment". Sharing the way these resources were developed is believed to foment new course proposals, in addition to being relevant not only for nursing, but also for other fields of knowledge that aim to offer courses in this teaching modality.

\section{METHOD}

This study is an experience report of the construction of the MOOC "Nursing Assessment", produced from 2015 to 2016. The course was elaborated by a multiprofessional team with three professors, one post-graduation student, and one undergraduate scholarship student from the Nursing School at UFRGS, in addition to a technical team (designers, an educator, and scholarship students) from the Center for the Support of Long-distance Learning (NAPEAD), from the Secretariat of Long-Distance Education (SEAD) at UFRGS.

The course was produced according to directives that guide the production of digital materials. At first, the instructional objectives of the course, and their adequacy with regards to the public they were destined to, were defined. Later, the team sought to get a closer experience of this type of course by enrolling in available MOOCs, which allowed them to have this experience as students. In the operational planning stage, the format of materials to be produced was determined, the financial viability of its execution was assessed, and a schedule was established. Starting from the moment content was defined, assessment activities and strategies were proposed in the form of scripts and storyboards. After the group of digital materials was finished (prototype), two stages of performance evaluation were carried out, one with professor-nurses with knowledge on the field, and later with users, in this case, Nursing undergraduate students. After the necessary adaptations to the reviews the project was finished and its product and process were evaluated ${ }^{(10-11)}$.

The course is hosted by the Lúmina platform at UFRGS, developed in 2016 specifically for this modality of courses in different fields of knowledge (https://lumina.ufrgs.br/). The course "Nursing Assessment" was the first to be made available, making it possible to test the usability of the platform. The course was evaluated in an exploratory research, which complied with ethical aspects such as previously asking for the consent of evaluators and keeping information anonymous ${ }^{(12)}$. This study was approved by the Research Ethics Committee of the institution (CAAE 56280516.7.0000.5347).

\section{- THE DEVELOPMENT OF THE MOOC “NURSING ASSESSMENT"}

During the choice and elaboration of the materials, the aim was conceiving a quality course that was attractive to the community. This trajectory is presented below with a description of the stages: choice of theme, course production, preliminary $\mathrm{MOOC}$ assessment, and release of the first edition.

\section{Choice of Theme}

The MOOC "Nursing Assessment" aims to offer the participant knowledge about the first stage of the Nursing Process (NP). The NP is the scientific method that gives support and systematize care in five related steps: assessment, diagnosing, planning, implementing, and evaluation ${ }^{(13)}$. Nursing eval 
assessments are carried out through anamnesis and physical exams, constituting the first stage of the NP. Although the subject is very important for the learning and practice of nursing, having a good grasp of "Nursing Process" knowledge and ability is a challenge that directly impacts clinical thinking and decision making processes ${ }^{(14)}$.

Therefore, the MOOC was organized according to the knowledge of Nursing undergraduates about how to start developing the NP. This is a cross-sectional theme in the syllabus of Nursing graduation courses, and an educational activity in this field is proposed here as a way to collaborate with the learning process.

\section{Course Production}

The course contents started with a video simulating a nursing consultation. It starred two professionals from the field (the patient was played by a nursing technician and the nurse by a nursing professional). The script was written by the work team itself, and involved a diabetic patient with foot lesions, who was at the nursing consultation due to complaints about how the lesions had repercussions on her daily activities. She was attended by a nurse who carried out a clinical nursing assessment. This video was used to trigger discussions, and the following modules referred to it. The video was filmed and edited by the NAPEAD team.

After the video was filmed, four 20-hour modules were organized and named: interview, physical examination, nursing records, and health need identification (Figure 1). The

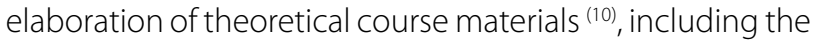
storyboard of the video classes, accompanying texts and exercises, was carried out by the professors and the master's degree student of the UFRGS Nursing School. Instructional design, including the production of videos and images and the upload of the materials to the Lúmina platform, were carried out by NAPEAD professionals.

The first stage of the course is a presentation of the organizers, clarifying how it works. Each model has one or two video classes, its own accompanying texts, a discussion forum for questions and for the application of learning activities with objective answers. To advance from a model to the next, participants must get $80 \%$ right answers in the exercises. They can try to achieve this score multiple times.

\section{MOOC Preliminary Evaluation}

For issues regarding material content and adequacy to be addressed ${ }^{(10)}$ in the MOOC, three professors from Undergraduate Nursing Courses with experience in the theme of the course and/or in the field of digital material development were invited to evaluate the material produced. The professors had access to the platform before the course was released and received an evaluation instrument containing 17 questions in a Likert scale, subdivided in three topics: objectives, structure/presentation, and relevance. After the evaluations were carried out, the following changes were made: the term "úlcera por pressão" (pressure ulcer) was replaced by "lesão por pressão" (pressure lesion); the spelling of the word "static" was corrected in the evaluative exercise in Module 2, and the fourth question of Module 3 was reviewed.

After the changes recommended by the experts were applied, the MOOC was made available for the students of the subject"Adult Nursing Care I"from the Nursing course at

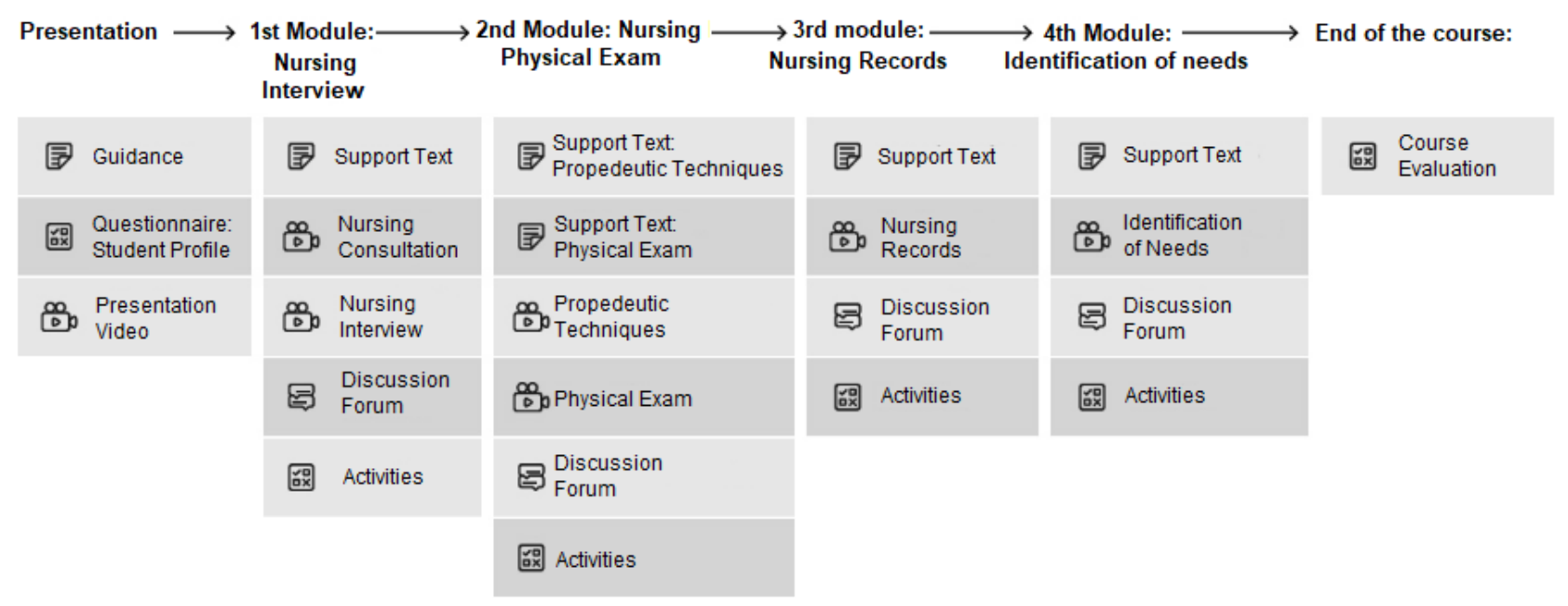

Figure 1 - Development of the interface of the Nursing Assessment MOOC Source: Lúmina Plafform/UFRGS. 
UFRGS in September 2016. The objective was verifying any aspects of the access to the platform that could be improved, regarding performing the activities and the usability of Lúmina, since it as the first actual use of the platform since its release. The analysis of this evaluation was important to observe the behavior of users and any needs to adjust the modules.

Among the students enrolled in the subject, 42 participated in this evaluation, from whom 37 finished all MOOC activities and completed an evaluation questionnaire at the end, which included: characterization data, Likert questions to evaluate the course, and two open questions to indicate aspects found to be positive or negative. Among the benefits of the course, students indicated the opportunity of using it to review the activities discussed in the classroom, found the support texts useful, and liked the fact that the course is online, meaning that doing the activities could be done with flexibility, with regards to time. They also highlighted the organization, objectivity, and clarity of the activities developed. The final score for the course was 8.6, and it met the expectations of $100 \%$ of the students who finished it, in accordance to the literature which states that MOOCs have high satisfaction levels ${ }^{(15)}$.

\section{First MOOC Edition}

Information on the course was disseminated via e-mail to national and international Universities in Portuguese-speaking countries, as well as in the UFRGS social networks and in the Rio Grande do Sul Regional Council of Nursing. The first edition of the MOOC "Nursing Evaluation" took place from November 6 to December 6, 2016. The course had a total of 693 students enrolled, from which 158 (22.8\%) finished the activities. From the 158 participants who concluded the course, 128 answered the online evaluation instrument. From these, 73 were nurses, 45 were undergraduate nursing students, 4 were nursing technicians, 1 was a nursing auxiliary, 1 was a clinical analysis technician, and 1 was a collective health student; 3 participants declined to answer.

Participation in the course was free and the participants who finished the MOOC could require from the UFRGS a certificate indicating they had finished the extension activity. After the first edition, some updates were included and the course, from its second edition on, was offered continuously. Since its release, in March 2019, 2442 participants enrolled in the MOOC "Nursing Evaluation". This massive enrollment of participants from the field of health is one of the main characteristics of the MOOCs, common for courses which had already had a large number of participants ${ }^{(15)}$.

\section{FINAL CONSIDERATIONS}

For the development of the $\mathrm{MOOC}$ to be possible, it was essential for the team to be multidisciplinary, adding, to the knowledge of the field by the professors of the Nursing School, the technological support of NAPEAD professionals to develop the digital structure and materials. The development of the Lúmina Platform was another factor that made it possible to host and give support to the MOOC "Nursing Assessment", which was an innovative initiative by the University.

The first experience with the undergraduate students and the expressive number of nurses who participated in the first edition showed that these courses can be used both as support to in-class teaching and for the continued education of health professionals. A limitation of this study is the fact that this was the first experiences the authors had in creating a MOOC. As a result, the development of more MOOC courses is recommended, especially with materials that simulate professional practices, to contribute for a more autonomous and significant learning process.

\section{REFERENCES}

1. Castañeda R, Garrison A, Haeberli P, Crump L, Zinsstag J, Ravel A, et al. First 'Global Flipped Classroom in One Health': from MOOCs to research on real world challenges. One Health. 2018:5:37-9. doi: https://doi.org/10.1016/j.onehlt. 2018.02.001

2. Barin CS, Bastos FP. Problematização dos M00C na atualidade: potencialidades e desafios. Renote: Novas Tecnol Educ. 2013;11(3). doi: https://doi.org/10.22456/ 1679-1916.44707

3. Teixeira AM, Miranda BA, Oliveira I, Pinto MCT. MOOC "Competências digitais para professores": uma prática inovadora. Rev Iberoam Educ Distancia. 2018;21(2):243-61. doi: https://doi.org/10.5944/ried.21.2.19784

4. Skiba D. Disruption in higher education: Massively Open Online Courses (M00Cs). Nurs Educ Perspect. 2012;33(6):416-7. doi: https://doi. org/10.5480/1536-5026-33.6.416

5. Shapiro HB, Lee CH, Wyman Roth NE, Li K, Çetinkaya-Rundel M, Canelas DA. Understanding the massive open online course (MOOC) student experience: an examination of attitudes, motivations, and barriers. Comput Educ. 2017;110:3550. doi: https://doi.org/10.1016/j.compedu.2017.03.003

6. Barba PG, Kennedy GE, Ainley MD. The role of students' motivation and participation in predicting performance in a MOOC. J Comput Assist Learn. 2016;32:218-31. doi: https://doi.org/10.1111/jcal.12130

7. Sims J. Communities of practice, telemedicine and online medical communities. Technol Forecast Soc Change. 2016;126:53-63. doi: https://doi.org/10.1016/j. techfore.2016.08.030

8. Alario-Hoyos C, Pérez-Sanagustín M, Cormier D, Delgado- Kloos C. Proposal for a conceptual framework for educators to describe and design M00Cs. J Univers Comput Sci. 2014;20(1):6-23. doi: https://doi.org/10.3217/jucs-020-01-0006 
9. Brites LS, Rocha CMF. Massive open online courses (M0OCs): perfil dos cursos no campo da saúde. Renote: Novas Tecnol Educ. 2017;15(1). doi: https://doi. org/10.22456/1679-1916.75097

10. Frey BA, Sutton JM. A model for developing multimidea learning projects. MERLOT J Online Learn Teach. 2010 [cited 2019 May 17];6(2):491-507. Available from: http://jolt.merlot.org/vol6no2/frey_0610.pdf

11. Cogo ALP, Perry GT, Santos MB. Produção de material digital para o ensino de enfermagem. Renote: Novas Tecnol Educ. 2015;13(2). doi: https://doi. org/10.22456/1679-1916.61460

12. Ministério da Saúde (BR). Conselho Nacional de Saúde. Resolução 466/2012. Dispõe sobre Diretrizes e normas regulamentadoras de pesquisa envolvendo seres humanos. Brasília, DF; 2013 [cited 2019 May 17]. Available from: http:// bvsms.saude.gov.br/bvs/saudelegis/cns/2013/res0466_12_12_2012.html

13. Santos N, Veiga P, Andrade R. Importância da anamnese e do exame físico para 0 cuidado do enfermeiro. Rev Bras Enferm. 2011;64(2):355-8. doi: https://doi. org/10.1590/S0034-71672011000200021
14. Carvalho EC, Oliveira-Kumakura ARS, Morais SCRVM. Clinical reasoning in nursing: teaching strategies and assessment tools. Rev Bras Enferm. 2017;70(3):662-8. doi: https://doi.org/10.1590/0034-7167-2016-0509

15. Stark CM, Pope J. Massive open online courses: how registered dietitians use MO0C's for nutrition education. J Acad Nutr Diet. 2014;114(8):1147-55. doi: https://doi.org/10.1016/j.jand.2014.04.001

Acknowledgements: UFRGS Secretariat of Distance Education (SEAD); National Council of Technological and Scientific Development (CNPq).

- Corresponding author:

Cibele Duarte Parulla

E-mail: cdparulla@gmail.com

\section{Associate editor:}

Ana Karina Silva da Rocha Tanaka

Editor-in-chief:

Approved: 08.15.2019
Maria da Graça Oliveira Crossetti 